\title{
Non Typical Presentation of Systemic Lupus Erythematosis
}

\author{
Maj L A S Abdul-Aziz* \\ MB, ChB, MRCPI, RAMC \\ Consultant Physician \\ BMH Rinteln BFPO 29
}

SUMMARY: A case of systemic lupus erythematosis (SLE) affecting the heart, joints, skin and kidneys is reported. Antinuclear antibodies were insignificant at presentation. Diagnosis was only possible with passage of time and renal biopsy.

\section{Case Report}

A 26 year old male caucasian who was fit enough to pass the Basic Fitness Test in 9 minutes presented with left shoulder pain which developed whilst on holiday in Hawaii in June 1988. Chest pain, shortness of breath and palpitations caused his hospital admission from exercise in October 1988.

On examination, he had a faint erythematous rash affecting the dorsum of both hands and forearms. Jugular venous pressure was elevated, but there was no dependent oedema, nor hepatosplenomegaly. Blood pressure was $125 / 80 \mathrm{~mm} \mathrm{Hg}$ with no paradox. He had pleural effusions on X-ray, and self terminating nodal tachycardia. A haemorrhagic pleural aspirate which measured $350 \mathrm{mls}$ in volume was negative for culture, but showed a total protein of $32.2 \mathrm{gm} / 1$. Erythrocyte sedimentation rate was $42 \mathrm{~mm} / 1 \mathrm{st} \mathrm{hr}$, haemoglobin was $13 \mathrm{gm} / \mathrm{dl}$, WCC was $9.7 \times 10^{9} / \mathrm{L}$, platelets $318 \times 10^{9} / 1$. Urea, electrolytes and liver function tests were normal.

Mid stream urine was negative for blood, protein and culture. Anti-nuclear factor was positive (speckled) 1:10, anti-double strand DNA negative and rheumatoid factor was positive at $62 \mathrm{IU} / \mathrm{ml}$. ECG showed Q waves in the inferior leads with ST elevation. This progressed to $\mathrm{T}$ inversion later. Cardiac enzymes were normal throughout.

Echocardiogram showed septal hypokinesia. Left ventricular internal dimensions in end systole increased from 2.96 to $3.84 \mathrm{~cm}$ (NR 2.5-4.1) and in end diastole from 4.41 to $5.23 \mathrm{~cm}$ (NR 3.5-5.6). Treatment with steriods was commenced because non-steroidal antiinflammatories had failed to improve his symptoms.

At this stage, he was referred to UK for further investigations and a diagnosis of Coxackie $B$ pericarditis was presumed, but the results of IgM enzyme linked immunosorbent assay (ELISA) failed to substantiate this diagnosis. His steroid treatment was tailed off over the next 3 months.

In March 1989 he developed chest pain due to oesphagitis secondary to his steroidal therapy. This finding was confirmed endoscopically.

Re-admission to hospital was precipitated in June 1989 when chest pain, shoulder pain, shortness of breath and palpitations recurred. Nodal tachycardia on this occasion was resistant to cardioversion and disopyramide (Rythmodan), but responded to an infusion of amiodarone.

${ }^{*}$ Now BMH Hong Kong BFPO 1

Proteinuria and haematuria first became a feature in July 1989. Intra-venous pyelography was normal. \&ै Cardiomegaly persisted on chest X-ray. Isotope cardiac ventriculogram showed a normal ejection fraction. Blood urea was $4.6 \mathrm{mmol} / 1$ (NR 1.5-7.5), creatinine 129 umol/1 (NR 67-125), serum total protein was $64.3 \mathrm{gm} / 1$ (NR 60-84), albumin $26.7 \mathrm{gm} / 1$ (NR 30-50), $\operatorname{lgG} 14.23$ $\mathrm{gm} / \mathrm{l}$ (NR 5.4-16.1), IgA $2.71 \mathrm{gm} / \mathrm{l}$ (NR 0.8-2.8), IgM $1.56 \mathrm{gm} / \mathrm{l}$ (NR 0.5-1.9), C3 $1.17 \mathrm{gm} / \mathrm{l}$ (NR 0.55-1.2), C4 $0.20 \mathrm{gm} / 1$ (NR 0.2-0.5) and creatinine clearance was 75 $\mathrm{ml} / \mathrm{min}$ (NR 80-120). Angiotensin converting enzyme level was normal, urinary protein excretion was $4.77 \mathrm{gm} /$ $24 \mathrm{hr}$ (NR $0-0.15$ ), protein selectivity was 0.12 (Highly selective). At this point, anti-double strand DNA and tibodies were positive.

It was thus apparent that he had systemic lupi erythematosis and a renal biopsy was arranged to cori firm the diagnosis. The histology showed mesangia proliferative lesions, consistent with a diagnosis of systemic lupus erythematosis (WHO Class IIIa).

$\mathrm{He}$ was started initially on prednisolone $30 \mathrm{mg} / \mathrm{dat}$ after confirmation of the diagnosis in August 1989. Duces to the lack of response prednisolone had to be increased to $60 \mathrm{mg} /$ day and later azathioprine was added in a dose of $100 \mathrm{mg} /$ day, this achieved a reduction in his urinary protein excretion (Table 1).

Prednisolone was reduced gradually to $15 \mathrm{mg}$ /day in addition to azathioprine $100 \mathrm{mg}$ /day and he was graded P7 Home only UK only. In February 1990 the typical skin rash became evident. In March 1990, his auto-antibody profile was negative (anti-nuclear factor, gastric parietal antibodies, smooth muscle antibodies, mitochrondrial antibodies, double stranded DNA, extractable nuclear antibodies (ENA), rheumatoid arthritis (RA) latex, and Rose-Waaler (RW) RA positive agglutination.

Table 1

24 Hr Urinary Protein \& Creatinine Clearance

\begin{tabular}{lrrlll}
\hline & $\begin{array}{c}\text { Creatinine } \\
\text { Clearance }\end{array}$ & $\begin{array}{c}\text { 24hr Urine Urine } \\
\text { Protein }\end{array}$ & Bp & Treatment \\
\hline July 89 & 75 & 4.00 & +++ & $125 / 75$ & \\
Sept 89 & 100 & 2.89 & +++ & $150 / 90$ & PN 30/D \\
Oct 89 & 83 & 5.43 & ++++ & $135 / 65$ & PN 60/D + AZA \\
Nov 89 & 92 & 5.18 & +++++ & $160 / 90$ & PN 30/D + AZA \\
Dec 89 & 161 & 3.72 & +++ & $150 / 90$ & PN 20/D + AZA \\
Jan 90 & 82 & 2.42 & ++ & $150 / 90$ & PN 15/D + AZA \\
Feb 90 & 62 & 2.46 & ++ & $130 / 85$ & PN 15/D + AZA \\
Oct 90 & & 0.71 & 0 & $142 / 66$ & PN 10/D + AZA \\
\hline
\end{tabular}


In July 1990 his anti-neutrophil cytoplasmic antibodies were negative.

Since posting in March 1990 he continues under review and is currently on $10 \mathrm{mg}$ prednisolone and $100 \mathrm{mg}$ azathioprine. He remains well.

\section{Discussion}

Systemic lupus erythematosis (SLE) is a multisystem inflammatory process. The diagnostic criteria for renal lupus according to the American Rheumatism Association $((1,2)$ are persistent Proteinuria $0.5 \mathrm{gm} /$ day, more than $3+$ Proteinuria or cellular casts.

When this patient presented initially it was acceptable to diagnose Coxackie virus although there were features that did not fit like the recurrence of inflammation and tachyarrhythmia. This diagnosis was discounted with the negative results of serology. An autoimmune process was suspected but the titres were minimally raised and double strand anti-DNA antibodies were only positive some months into the illness.

Renal and typical skin involvement became apparent thirteen months after his initial presentation. Myopericarditis was diagnosed on the strength of the abnormalities ECG, echocardiography and the development of runs of tachyarrhythmia.

According to Esdaile and co workers and Austin $(3,4)$, the outcome in lupus nephritis depends on the presence of bad prognostic features which are shown in Table 2.

Table 2

Bad prognostic features for patients with SLE nephritis
a. Age below 23 Yrs.
b. Male sex.
c. Serum creatinine $>140 \mathrm{umol} / 1$.
d. Chronicity of nephritis on histology (WHO Class IV).
e. Level of $\mathrm{C} 3<0.6 \mathrm{gm} / 1$.
f. 24 hour urinary excretion of protein $>3 \mathrm{gm} / 24 \mathrm{hr}$.
g. Low socio-economic class.
h. Vasculitis.
i. Hypertension.
j. Comorbid illness at time of biopsy.

According to these criteria this patient was judged to be in need of cytotoxic drugs as well as prednisolone $(5,6)$.

Other conditions such as systemic vasculitis and idiopathic necrotising and cresentic glomerulonephritis were excluded by the negative anti-neutrophil cytoplasmic autoantibodies (ANCA) (7).

\section{Acknowledgement}

I am indebted to Colonel R C Menzies L/RAMC for his critical appraisal of the paper, to Major M J World for performing the renal biopsy and to St Thomas' Hospital Histology Department.

\section{REFERENCES}

1. Cohen A S, Reynolds W E, Franklin E C, et al. Preliminary criteria for the classification of systemic lupus erythematosis. Bull Rheum Dis 1971;21:643648.

2. TAN E M, Cohen A S, Fries J F, et al. The 1982 revised criteria for the classification of systemic lupus erythematosis. Arthritis Rheum 1982;25:671-677.

3. Esdaile J M, Livinton C, Federgreen W, et al. The clinical and renal biopsy predictors of long termoutcome in lupus nephritis. A study of 87 patients and review of the literature. $Q J M e d 1989 ; 269: 779-$ 833.

4. Austin III H A, Muenz L R, Joyce K M, et al. Pro-g gnostic factors in lupus nephritis: contribution of renal histologic data. Am JMed 1983;75:382-391.

5. Carett S, Kippel J H, Decker J L, et al. Controlled studies of oral immunosuppressive drugs in lupusa nephritis. Ann Intern Med 1983;99:1-8.

6. Austin III H A, Kippel J H, Balow J E, et al. Therapy in lupus nephritis, controlled trial of prednisone and cytotoxic drugs. NEngl JMed 1986;314:614-9.

7. Falk R J, JenNetTe J C. Anti-neutrophil cytoplasmic antibodies with specificity for myloperoxidase in patients with systemic vasculitis and idiopathic necrotising and cresentic glomerulonephritis. $N E n g l$ JMed 1988;318:1651-7. 